\title{
Early weaning and concentrate supplementation on the performance and metabolic profile of grazing lambs ${ }^{1}$
}

\section{Sergio Rodrigo Fernandes ${ }^{2}$, Alda Lúcia Gomes Monteiro ${ }^{3}$, Rosangela Locatelli Dittrich ${ }^{4}$, Jordana Andrioli Salgado ${ }^{2}$, Cláudio José Araújo da Silva ${ }^{5}$, Marina Gabriela Berchiol da Silva ${ }^{5}$, Olair Carlos Beltrame ${ }^{2}$, Pedro Henrique Nicolau Pinto ${ }^{2}$}

\footnotetext{
1 Partially financed by CNPq and Fundação Araucária.

2 Programa de Pós-Graduação em Ciências Veterinárias - UFPR, Curitiba-PR.

${ }^{3}$ Departamento de Zootecnia - UFPR, Curitiba-PR.

${ }^{4}$ Departamento de Medicina Veterinária - UFPR, Curitiba-PR.

5 Programa de Pós-Graduação em Agronomia - UFPR, Curitiba-PR.
}

\begin{abstract}
This study was designed to investigate the effect of early weaning and concentrate supplementation on performance and metabolic profile of lambs in four production systems on pasture: suckling lambs not supplemented until slaughter; suckling lambs supplemented with concentrate in creep feeding until slaughter; early weaned lambs not supplemented until slaughter; early weaned lambs supplemented with concentrate until slaughter. Performance was assessed by average daily gain (ADG) and body condition score (BCS) measurements. Metabolic profile was delineated by measuring serum albumin, urea, creatinine, cholesterol, glucose and aspartate aminotransferase. Weaning reduced ADG by $92 \mathrm{~g} / \mathrm{d}$ and the ADG for weaned and suckling lambs were $113 \mathrm{~g} / \mathrm{d}$ and $205 \mathrm{~g} / \mathrm{d}$, respectively. Supplementation increased ADG by $117 \mathrm{~g} / \mathrm{d}$ and the ADG was $99 \mathrm{~g} / \mathrm{d}$ for non-supplemented and $216 \mathrm{~g} / \mathrm{d}$ for supplemented lambs. Body weight and BCS at the end of trial were lower in weaned and non-supplemented animals (20.7 kg and 1.5 points), and higher in those on creep feeding (35.3 $\mathrm{kg}$ and 3.3 points). Weaning decreased serum levels of albumin, cholesterol and aspartate aminotransferase. Supplementation increased serum albumin and decreased serum aspartate aminotransferase. Serum urea was not affected by weaning or supplementation and remained high during the trial. Serum creatinine and glucose were lower in weaned and non-supplemented lambs. Early weaning generates unsuitable metabolic profile and low performance and may not be recommended as single strategy to produce lambs on pasture Concentrate supplementation has similar response to suckling on the performance and metabolic profile of animals, and may be considered an efficient strategy to improve the nutritional status of early weaned lambs.
\end{abstract}

Key Words: average daily gain, concentrate feed, energy, growth, protein, suckling

\section{Introduction}

Several strategies have been studied to maximize animal productivity and improve economic results in Brazilian lamb meat production. Early weaning at 45 to 60 days of age is a common management practice in intensive lambing systems, as well as the use of concentrate supplementation for grazing lambs. Both techniques have been widely applied on lamb production systems on pasture.

Recent studies have shown good results for lamb performance and productivity in response to concentrate supplementation on pasture (Carvalho et al., 2007; Elejalde et al., 2010). Conversely, early weaning yields low performance and productivity for lambs maintained exclusively on pasture (Poli et al., 2008; Ribeiro et al., 2009). Performance has been related to changes in nutritional and metabolic status. Evaluations of metabolic profile by blood parameters determination suggests reliable references for interpreting performance results with greater accuracy, thus, qualifying the nutritional status.

Lambs kept only on pasture have limited weight gain as consequence of both the low energy intake by forage and low ruminal fermentation capacity. Concentrate feed, in addition to increasing dietary energy intake, has positive effects on rumen development (Baldwin et al., 2004), resulting on higher weight gain for supplemented grazing lambs. Accordingly, the low performance of early weaned lambs kept only on pasture may be improved by concentrate supplementation. Average performance increase of $90 \mathrm{~g} / \mathrm{d}$ has been observed in lambs supplemented daily with concentrate of $20 \mathrm{~g} / \mathrm{kg}$ of body weight (BW) (Carvalho et al., 2007; Souza et al., 2010).

Suckling is important for lamb nutrition, mainly by improving energy intake. Poli et al. (2008) and Ribeiro et al. (2009) observed that suckling lambs showed performance $181 \mathrm{~g} / \mathrm{d}$ superior to those weaned early and kept only on 
pasture, with means of $292 \mathrm{~g} / \mathrm{d}$ for non-weaned and $111 \mathrm{~g} / \mathrm{d}$ for weaned lambs. Consequently, keeping the lambs with dams on high quality pasture is sufficient to meet their nutritional requirements and obtain higher performance results.

Early weaning and concentrate supplementation strategies affect lamb nutritional status and performance. However, few studies have been conducted to characterize metabolic status of animals submitted to different production systems on pasture. This study was designed to investigate the effect of early weaning and concentrate supplementation on performance and serum levels of blood metabolites of grazing lambs.

\section{Material and Methods}

The experiment was conducted between November/ 2008 and March/2009 at the Laboratory of Production and Research of Sheep and Goats (LAPOC), Universidade Federal do Paraná (UFPR), located in Pinhais-PR (25 25' South, 49 8' West, and altitude of $915 \mathrm{~m}$ ).

Four production systems were established on Tifton85 (Cynodon spp.) pasture: suckling lambs not supplemented until slaughter; suckling lambs supplemented with concentrate in creep feeding until slaughter; early weaned lambs not supplemented until slaughter; and early weaned lambs supplemented with concentrate until slaughter.

The trial was accomplished in randomized blocks design with three replications and three lambs per replication. The paddocks were the experimental units and the lambs in test were the observation units. The blocks were defined based on ewes age, which differed $(\mathrm{P}<0.05)$ in six months for each block with average of 4.5 years.

Thirty-six Suffolk lambs (24 females and 12 noncastrated males) were distributed into the systems according to sex, BW and type of birth (single or twin). Their distribution into the experimental units was uniform and characterized by two females and one non-castrated male and by two twin lambs plus one single lamb per paddock. The BW and the age of lambs at the beginning of trial were $16.7 \pm 0.7 \mathrm{~kg}$ and $46 \pm 1$ days (mean \pm standard error $-\mathrm{SE}$ ), respectively. The trial lasted 98 days and finished at $144 \pm 2$ days (mean \pm SE) of mean age for all systems.

The lambs were weaned at $46 \pm 1$ days (mean \pm SE) of age and immediately allocated into the paddocks of the early weaning systems. Eighteen ewes with $4.4 \pm 0$.3 years of age and $92.4 \pm 1.9 \mathrm{~kg} \mathrm{BW}$ (mean $\pm \mathrm{SE}$ ) were allocated into paddocks of the systems without weaning. Three ewes were homogeneously distributed in each paddock according to age defined for each block and kept with their offspring during the trial period.

The parasitological monitoring was made every 21 days by assessing the degree of anemia according to the Famacha ${ }^{\circledR}$ method (Molento et al., 2004) and also fecal eggs counting by the modified McMaster technique (Gordon \& Whitlock, 1939). Anthelmintic treatment (Moxidectin at $0.2 \%-1 \mathrm{~mL} / 10 \mathrm{~kg} \mathrm{BW}$ and Nitroxinil at $34 \%-2 \mathrm{~mL} / 50 \mathrm{~kg} \mathrm{BW}$ ) was administered to lambs with Famacha equal to or higher than 3 and fecal eggs counting equal to or higher than 700 .

In the systems with supplementation, lambs received daily a protein-energy concentrate supplement in $20 \mathrm{~g} / \mathrm{kg}$ BW on dry matter (DM) basis. The supplement was composed, on as fed basis, of $400 \mathrm{~g} / \mathrm{kg}$ soybean meal, $400 \mathrm{~g} / \mathrm{kg}$ ground corn grain, $150 \mathrm{~g} / \mathrm{kg}$ wheat bran, $20 \mathrm{~g} / \mathrm{kg}$ mineral supplement (Ovinophós ${ }^{\circledR}$ ), $25 \mathrm{~g} / \mathrm{kg}$ limestone and $5 \mathrm{~g} / \mathrm{kg}$ sodium chloride. The supplement was offered in the afternoon (16:30 h) and adjustments were made on 21-day intervals based on the lamb weight after fasting (feed and water, for $12 \mathrm{~h}$ ).

The continuous grazing method was used with variable stocking according to "put and take" technique (Mott \& Lucas, 1952). The adjustments were made every 21 days to maintain forage allowance at $12 \mathrm{~g} / \mathrm{kg} \mathrm{BW}$ in DM/d and maximize weight gain (Hodgson, 1990). Forage allowance was calculated using the green forage mass ( $\mathrm{kg} \mathrm{DM} / \mathrm{ha}$ ), the forage accumulation rate ( $\mathrm{kg} \mathrm{DM} / \mathrm{ha} / \mathrm{d}$ ) and the animal BW per area (kg BW/ha), according to Soares et al. (2006). Green forage mass was determined by the separation of fractions of green forage and dead/senescent material, from three forage samples harvested per paddock. These fractions were dried in forced-ventilation oven at $65^{\circ} \mathrm{C}$ until constant weight. After the drying process, the fractions were weighed. The green forage fraction was used to estimate green forage mass and to calculate forage allowance. Forage accumulation rate was estimated according to Campbell (1966). Animal BW per area was calculated considering the lambs BW on systems with weaning and the ewes plus lambs BW on systems without weaning. The animal unit was characterized by lamb and ewe plus lamb on the systems with and without weaning, respectively. An animal unit of extra animals maintained in similar grazing conditions that of the test animals was added or removed from the paddocks to maintain the pre-established forage allowance.

The nutritional composition of forage was determined at the beginning, the middle and at the end of trial from samples harvested from each paddock by simulated grazing, according to "hand plucking” technique (Burns et al., 1989). The samples were weighed immediately after harvest and 
dried in forced-ventilation oven at $65{ }^{\circ} \mathrm{C}$ until constant weight. After the drying process, the samples were weighed to estimate the forage DM content and ground in Wiley mill with a 1-mm sieve for chemical analysis.

Chemical analysis of the forage and the concentrate supplement (Table 1) were performed at the Laboratory of Animal Nutrition, at UFPR, where the levels of neutral detergent fiber (NDF) and acid detergent fiber (ADF) contents were determined according to Van Soest et al. (1991). Crude protein (CP), ether extract (EE), lignin (LIG), ash, calcium ( $\mathrm{Ca}$ ) and phosphorus (P) contents were determined according to Silva \& Queiroz (2002). Metabolizable energy (ME) was calculated using the equations described in the NRC (2001).

Lambs were weighed after fasting (feed and water, for $12 \mathrm{~h}$ ) in pre-trial period at $32 \pm 1$ days (mean $\pm \mathrm{SE}$ ) of age and every 21 days in trial period. The performance was assessed based on weights at 46 and 144 days of age, which correspond to weight at the beginning and the end of the trial, respectively. Average daily gain (ADG) was calculated using final minus initial BW divided by trial period (98d). Body condition score (BCS) was assessed in the lumbar region using a 5-point scale divided into 0.5 (Russel et al., 1969) at the beginning and at the end of trial.

Lamb metabolic profile was assessed by serum levels of blood metabolites. The first evaluation was performed in pre-trial period at 32 days of age to identify the initial metabolic condition of the animals. Evaluations of metabolic profile were performed every 21 days, totaling six evaluations. Blood samples were collected by jugular venipuncture in the morning, between 08h30 and 09h30, after fasting (feed and water for $12 \mathrm{~h}$ ). Samples were maintained motionless for 30 min to complete coagulation, and then centrifuged (3000 rpm for $10 \mathrm{~min}$ ) for serum separation. Using the semiautomatic biochemical analyzer CELM SBA 200 and

Table 1 - Mean contents of dry matter and nutritional composition of concentrate supplement and forage sampled by simulated grazing at the beginning, the middle and at the end of the trial period in the Tifton-85 pasture production systems

\begin{tabular}{lcc}
\hline Composition & $\begin{array}{c}\text { Protein-energy } \\
\text { concentrate }\end{array}$ & Forage \\
\hline Dry matter (DM, g/kg as fed) & 881.5 & 274.3 \\
Crude protein (g/kg DM) & 254.7 & 218.6 \\
Eter extract (g/kg DM) & 31.7 & 40.3 \\
Neutral detergent fiber (g/kg DM) & 201.2 & 704.2 \\
Acid detergent fiber (g/kg DM) & 76.7 & 290.6 \\
Lignin (g/kg DM) & 10.9 & 33.9 \\
Ash (g/kg DM) & 76.6 & 62.0 \\
Calcium (g/kg DM) & 13.2 & 5.8 \\
Phosphorus (g/kg DM) & 6.2 & 5.6 \\
Metabolizable energy (Mcal/kg DM) & 3.04 & 2.34 \\
\hline
\end{tabular}

commercial kits from Human ${ }^{\circledR}$, the serum levels of albumin (BCG colorimetric method, kit No. 001), urea (GLDH kineticenzymatic method, kit No. 10521-P), creatinine (Jaffé kineticcolorimetric method, kit No. 030), cholesterol (LCF enzymaticcolorimetric method, kit No. 10013), glucose (GOD-PAP enzymatic-colorimetric method, kit No. 10261) and aspartate aminotransferase (UV kinetic method, kit No. 12301) were determined. Analyses were performed at the Laboratory of Veterinary Clinical Pathology, at UFPR.

Growth measurements and the parameters of metabolic profile were analyzed by ANOVA using the general linear model (GLM) procedure for randomized blocks in a $2 \times 2$ factorial arrangement, which allowed to evaluate the effects of early weaning and concentrate supplementation on the studied variables. Interactions with significance $(\mathrm{P}<0.05)$ between early weaning and concentrate supplementation means were compared by the Tukey test $(\mathrm{P}<0.05)$. Statistical analyses were performed using the statistical package SAEG (Sistema para Análises Estatísticas, version 9.1).

\section{Results and Discussion}

Body weight (BW) at 32 days of age, initial BW and initial BCS were similar $(\mathrm{P}>0.05)$ between the groups of lambs distributed on the different production systems and showed means of $12.8 \mathrm{~kg}, 16.7 \mathrm{~kg}$ and 2.6 points, respectively (Table 2).

Lamb performance was affected by weaning and supplementation (Table 2 ). Weaning reduced $(\mathrm{P}<0.05)$ ADG by $92 \mathrm{~g} / \mathrm{d}$ and the ADG for weaned and suckling lambs were $113 \mathrm{~g} / \mathrm{d}$ and $205 \mathrm{~g} / \mathrm{d}$, respectively. Supplementation increased $(\mathrm{P}<0.05)$ ADG by $117 \mathrm{~g} / \mathrm{d}$ and the ADG was $99 \mathrm{~g} / \mathrm{d}$ for nonsupplemented and $216 \mathrm{~g} / \mathrm{d}$ for supplemented lambs.

Interaction between weaning and supplementation $(\mathrm{P}<0.05)$ was observed for final BW and final BCS (Table 2), which were lower in weaned and non-supplemented lambs (20.7 kg and 1.5 points) and higher in lambs supplemented on creep feeding ( $35.3 \mathrm{~kg}$ and 3.3 points, Table 3 ).

Higher ADG for suckling lambs and for supplemented lambs was shown by high feeding value and high energetic density of milk and concentrate. According to Baldwin et al. (2004), the high energetic density feed intake by young ruminants allows to accelerate the rumen development, resulting in rumen mass increases and papillae growth in ruminal epithelium. This occurs in response to the presence of short-chain fatty acids in the ruminal lumen, which are produced in higher quantity and proportion by intake of milk and, mainly, concentrated feed. Similarly, final BW and final BCS were positively related to high-quality diet characterized by milk and/or concentrate intake. Thus, 
Table 2 - Results of ANOVA for lamb growth measurements in response to weaning and supplementation on Tifton-85 pasture production systems

\begin{tabular}{|c|c|c|c|c|c|c|}
\hline \multirow[t]{2}{*}{ Growth measurements } & \multicolumn{3}{|c|}{ P-value } & \multirow[t]{2}{*}{ Mean } & \multirow[t]{2}{*}{$\mathrm{SE}$} & \multirow[t]{2}{*}{$r^{2}$} \\
\hline & $\mathrm{W}$ & $\mathrm{S}$ & $\mathrm{W} \times \mathrm{S}$ & & & \\
\hline $\mathrm{BW}_{32 \mathrm{~d}}(\mathrm{~kg})$ & 0.6448 & 0.1804 & 0.0635 & 12.8 & 0.6 & 0.25 \\
\hline $\mathrm{BW}_{\mathrm{F}}(\mathrm{kg})$ & 0.0000 & 0.0000 & 0.0148 & 30.2 & 1.2 & 0.72 \\
\hline ADG $(g / d)$ & 0.0000 & 0.0000 & 0.6182 & 163 & 16 & 0.78 \\
\hline $\mathrm{BCS}_{\mathrm{I}}(1-5)$ & 0.8733 & 0.4786 & 0.1493 & 2.6 & 0.1 & 0.16 \\
\hline
\end{tabular}

$\mathrm{BW}_{32 \mathrm{~d}}$ - body weight at 32 days of age; $\mathrm{BW}_{\mathrm{I}}$ - initial body weight; $\mathrm{BW}_{\mathrm{F}}$ - final body weight; $\mathrm{ADG}$ - average daily gain; $\mathrm{BCS}_{\mathrm{I}}$ - initial body condition score; $\mathrm{BCS}_{\mathrm{F}}$ - final body condition score.

$\mathrm{W}$ - weaning; S - supplementation; $\mathrm{W} \times \mathrm{S}$ - weaning $\times$ supplementation interaction.

$\mathrm{SE}$ - standard error; $\mathrm{r}^{2}$ - determination coefficient.

suckling and/or supplemented lambs showed higher weight and better body condition than weaned and nonsupplemented animals at the end of trial (Table 3).

Lower ADG for weaned and for non-supplemented lambs may have been caused by limitation in forage intake due to higher fiber content $(\mathrm{NDF}=704.2 \mathrm{~g} / \mathrm{kg} \mathrm{DM}$; Table 1 ) (Allen, 1996). Moreover, the late development of the rumen may have determined the lower utilization of ingested forage, which also had negative impact on lamb ADG. Both factors contributed to the lower weight and the poor body condition observed for weaned and non-supplemented animals (Table 3). The final BW and BCS obtained on this production system were unsuitable for slaughter, as it was reported to

Table 3 - Weaning and supplementation interaction for final body weight $\left(\mathrm{BW}_{\mathrm{F}}\right)$ and final body condition score $\left(\mathrm{BCS}_{\mathrm{F}}\right)$ of lambs raised on Tifton-85 pasture

\begin{tabular}{lccc}
\hline $\begin{array}{l}\text { Growth } \\
\text { measurements }\end{array}$ & Weaning & \multicolumn{2}{c}{ Supplementation } \\
\cline { 3 - 4 } & & $\mathrm{S}_{0}$ & $\mathrm{~S}_{1}$ \\
\hline $\mathrm{BW}_{\mathrm{F}}(\mathrm{kg})$ & $\mathrm{W}_{0}$ & $31.3 \mathrm{Ab}$ & $35.3 \mathrm{Aa}$ \\
& $\mathrm{W}_{1}$ & $20.7 \mathrm{Bb}$ & $32.1 \mathrm{Aa}$ \\
$\mathrm{BCS}_{\mathrm{F}}(1-5)$ & $\mathrm{W}_{0}$ & $3.0 \mathrm{Aa}$ & $3.3 \mathrm{Aa}$ \\
& $\mathrm{W}_{1}$ & $1.5 \mathrm{Bb}$ & $2.6 \mathrm{Ba}$ \\
\hline
\end{tabular}

$\mathrm{W}_{0}$ - non-weaned; $\mathrm{W}_{1}$ - weaned; $\mathrm{S}_{0}$ - non-supplemented; $\mathrm{S}_{1}$ - supplemented. Means followed by different capital letters in the same column and different lowercase letters in the same row show difference on Tukey test $(\mathrm{P}<0.05)$. result in lighter carcasses with low yield and fat content (Carvalho et al., 2007; Fernandes et al., 2011).

Lambs metabolic profile at 32 days of age was similar ( $\mathrm{P}>0.05$ ) between groups distributed on the production systems and indicated that they were subjected to similar management during the pre-trial period. The values (mean \pm SE) obtained for blood metabolites corresponded to $35.0 \pm 0.5 \mathrm{~g} / \mathrm{L}$ for serum albumin, $11.23 \pm 0.50 \mathrm{mmol} / \mathrm{L}$ for serum urea, $66.70 \pm 2.18 \mu \mathrm{mol} / \mathrm{L}$ for serum creatinine, $3.18 \pm 0.13 \mathrm{mmol} / \mathrm{L}$ for serum cholesterol, $4.54 \pm 0.16 \mathrm{mmol} / \mathrm{L}$ for serum glucose and $86.4 \pm 2.8 \mathrm{U} / \mathrm{L}$ for serum aspartate aminotransferase. However, the metabolic profile changed in the trial period (Table 4).

Weaning and supplementation affected lamb protein profile, causing changes in serum albumin (Table 4), which was lower $(\mathrm{P}<0.05)$ for weaned animals $(34.1 \mathrm{~g} / \mathrm{L})$ compared with suckling ones $(36.9 \mathrm{~g} / \mathrm{L})$. Also, it was higher $(\mathrm{P}<0.05)$ for supplemented lambs (36.4 g/L), compared with nonsupplemented ones $(34.7 \mathrm{~g} / \mathrm{L})$. Serum albumin remained above the superior limit for adult sheep (30 g/L; Table 4) which suggests the correlation between this metabolite with age. According to Eckersall (2008), the serum level of albumin is negatively correlated to the age, and is stabilized in adult animals.

Table 4 - Results of ANOVA for serum levels of blood metabolites of the lambs in response to weaning and supplementation on Tifton85 pasture production systems

\begin{tabular}{|c|c|c|c|c|c|c|c|}
\hline \multirow[t]{2}{*}{ Blood metabolites } & \multicolumn{3}{|c|}{ P-value } & \multirow[t]{2}{*}{ Mean } & \multirow[t]{2}{*}{ SE } & \multirow[t]{2}{*}{$\mathrm{r}^{2}$} & \multirow[t]{2}{*}{ Reference values ${ }^{1}$} \\
\hline & W & $\mathrm{S}$ & $\mathrm{W} \times \mathrm{S}$ & & & & \\
\hline Albumin (g/L) & 0.0000 & 0.0081 & 0.3416 & 35.51 & 0.38 & 0.56 & $24-30$ \\
\hline Urea (mmol/L) & 0.1983 & 0.2260 & 0.4635 & 9.76 & 0.23 & 0.21 & $2.86-7.14$ \\
\hline Creatinine $(\mu \mathrm{mol} / \mathrm{L})$ & 0.0004 & 0.8146 & 0.0300 & 71.92 & 1.12 & 0.46 & $106-168$ \\
\hline Cholesterol (mmol/L) & 0.0013 & 0.0759 & 0.5377 & 2.08 & 0.05 & 0.36 & $1.35-1.97$ \\
\hline Glucose (mmol/L) & 0.3249 & 0.0003 & 0.0441 & 4.73 & 0.08 & 0.46 & $2.78-4.44$ \\
\hline AST (U/L) & 0.0121 & 0.0001 & 0.5270 & 120.92 & 3.04 & 0.55 & $60-280$ \\
\hline
\end{tabular}

AST - aspartate aminotransferase.

$\mathrm{W}$ - weaning; S - supplementation; $\mathrm{W} \times \mathrm{S}$ - weaning $\times$ supplementation interaction.

$\mathrm{SE}$ - standard error; $\mathrm{r}^{2}$ - determination coefficient.

${ }^{1}$ Reference values for adult sheep (Kaneko et al. 2008). 
Intake of milk or concentrated supplement determined similar response into serum albumin, which remained near or above the average $(35.5 \mathrm{~g} / \mathrm{L})$ in animals that had access to these sources of nutrients (Figure 1).

The largest quantity of protein and energy provided by concentrate feed $(\mathrm{CP}=254.7 \mathrm{~g} / \mathrm{kg} \mathrm{DM}, \mathrm{ME}=3.04 \mathrm{Mcal} / \mathrm{kg}$ DM; Table 1) explains the higher serum albumin in supplemented lambs. Despite showing only $55 \mathrm{~g} / \mathrm{kg}$ DM in CP (Pulina \& Nudda, 2004), milk determined greater energy intake to the diet and promoted better use of available forage protein, resulting in increased serum albumin in suckling lambs. Maximum levels of albumin synthesis can be achieved when the amino acid requirements are fully met, which features an important metabolic pathway due to the albumin function as protein reserve used in nutritional deficiency situations (Caldeira, 2005). Therefore, higher serum albumin was expected in lambs that ingested milk, concentrate supplement or both.

Serum urea was not affected $(\mathrm{P}>0.05)$ by weaning or supplementation, with average of $9.76 \mathrm{mmol} / \mathrm{L}$, remaining

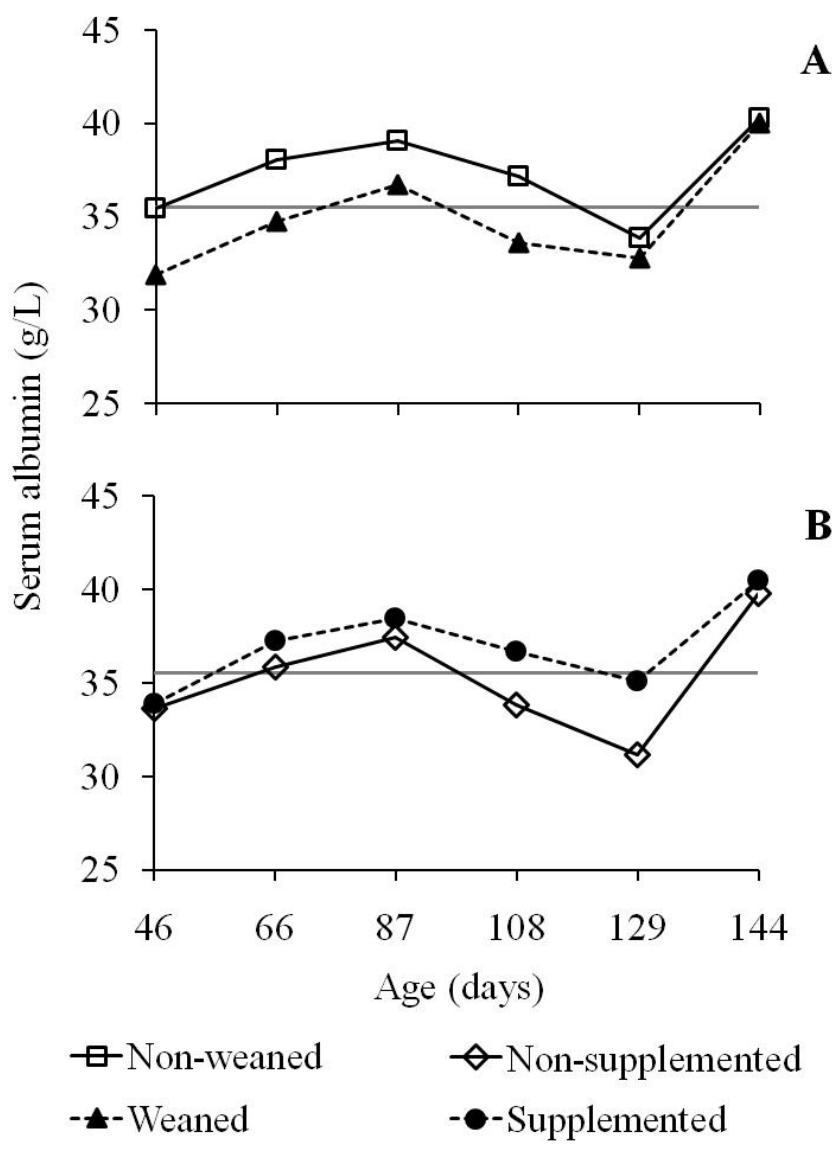

The line represents the mean serum albumin (35.51 g/L) for all systems.

Figure 1 - Dynamic of serum albumin levels in relation to age of lambs subjected or not to weaning (A) and supplementation (B). above the superior limit established for adult sheep (7.14 mmol/L; Table 4). This indicates a protein and energy imbalance caused by excessive protein intake in all the evaluated systems. The increase in serum urea occurred in response to the excess of ammonia derived from the fermentation of large protein amounts in the rumen (Caldeira, 2005). Also, the production of ammonia in the rumen is enhanced by intake of feed with high solubility protein fractions, such as grain-based concentrate (Sniffen et al., 1992) and forage with high proportion of leaves (Poppi \& McLennan, 1995). In fact, the morphological composition of the samples harvested by grazing simulation indicated that the lambs fed forage showed $86 \%$ of leaves (CP = 218.6 g/kg DM; Table 1), on average, for all systems.

Although the energy level of the diet was increased by the intake of milk and/or concentrate supplement, the higher energy intake did not reduce protein losses as urea. This has an important nutritional implication as the process of synthesis and excretion of urea involves energy expenditure (Kozloski, 2009), which could be used in muscle deposition metabolism.

Interaction between weaning and supplementation $(\mathrm{P}<0.05)$ was observed for serum creatinine (Table 4 ) which was lower in weaned and non-supplemented lambs (Table 5). Serum creatinine ranged from 66 to $77 \mu \mathrm{mol} / \mathrm{L}$, which is lower than the limit set for adult sheep (106 $\mu \mathrm{mol} / \mathrm{L}$; Table 4$)$.

Creatinine is produced from creatine and phosphocreatine catabolism that are present in the muscle (Richardson et al., 2004), and its serum level is positively correlated to muscle mass (Caldeira et al., 2007). This explains the low serum creatinine levels in relation to reference values for adult sheep and the differences between the evaluated systems. In the first case, the lowest serum creatinine reflects the lower muscle mass in lambs when compared with adult sheep, from which the values of biochemical reference were determined. In the second case, the lowest serum creatinine in weaned and non-supplemented lambs indicates lower intensity of protein metabolism associated with synthesis and deposition of muscle tissue.

Table 5 - Weaning and supplementation interaction for serum creatinine of lambs raised on Tifton-85 pasture

\begin{tabular}{lccc}
\hline $\begin{array}{l}\text { Blood } \\
\text { metabolite }\end{array}$ & Weaning & \multicolumn{2}{c}{ Supplementation } \\
\cline { 3 - 4 } & & $\mathrm{S}_{0}$ & $\mathrm{~S}_{1}$ \\
\hline Creatinine $(\mu \mathrm{mol} / \mathrm{L})$ & $\mathrm{W}_{0}$ & $77.25 \mathrm{Aa}$ & $73.61 \mathrm{Aa}$ \\
& $\mathrm{W}_{1}$ & $66.04 \mathrm{Ba}$ & $70.65 \mathrm{Aa}$ \\
\hline $\mathrm{W}_{0}$ - non-weaned; $\mathrm{W}_{1}$ - weaned; $\mathrm{S}_{0}$ - non-supplemented; $\mathrm{S}_{1}$ - supplemented. \\
\multicolumn{2}{l}{ Means followed by different capital letters in the same column, and different }
\end{tabular}

lowercase letters in the same row show difference on Tukey test $(\mathrm{P}<0.05)$. 
Higher variation for serum creatinine during the trial period was observed in non-supplemented lambs compared with those supplemented (Figure 2) with values of $71.64 \pm 2.07 \mu \mathrm{mol} / \mathrm{L}$ and $72.2 \pm 0.82 \mu \mathrm{mol} / \mathrm{L}($ mean $\pm \mathrm{SE}$ ), respectively.

Progressive decrease of serum creatinine in nonsupplemented lambs was caused by the low energy density from ingested forage ( $\mathrm{ME}=2.34 \mathrm{Mcal} / \mathrm{kg} \mathrm{DM}$; Table 1) leading to a reduction in turnover rates of muscle energy reserves. This response was not observed in suckling and non-supplemented lambs, in which serum creatinine remained above or near the average $(71.92 \mu \mathrm{mol} / \mathrm{L})$, indicating that milk is an important source of energy and contributes effectively to increasing turnover rates of muscle energy reserves. Also, the intake of concentrate supplement allowed serum creatinine to remain close to the average and with a low variation during the trial period, regardless of the weaning (Figure 2). These results suggest the positive influence of milk and/or supplement intake in lamb protein metabolism, increasing synthesis of muscle tissue and renewal of energy reserves in the muscle.

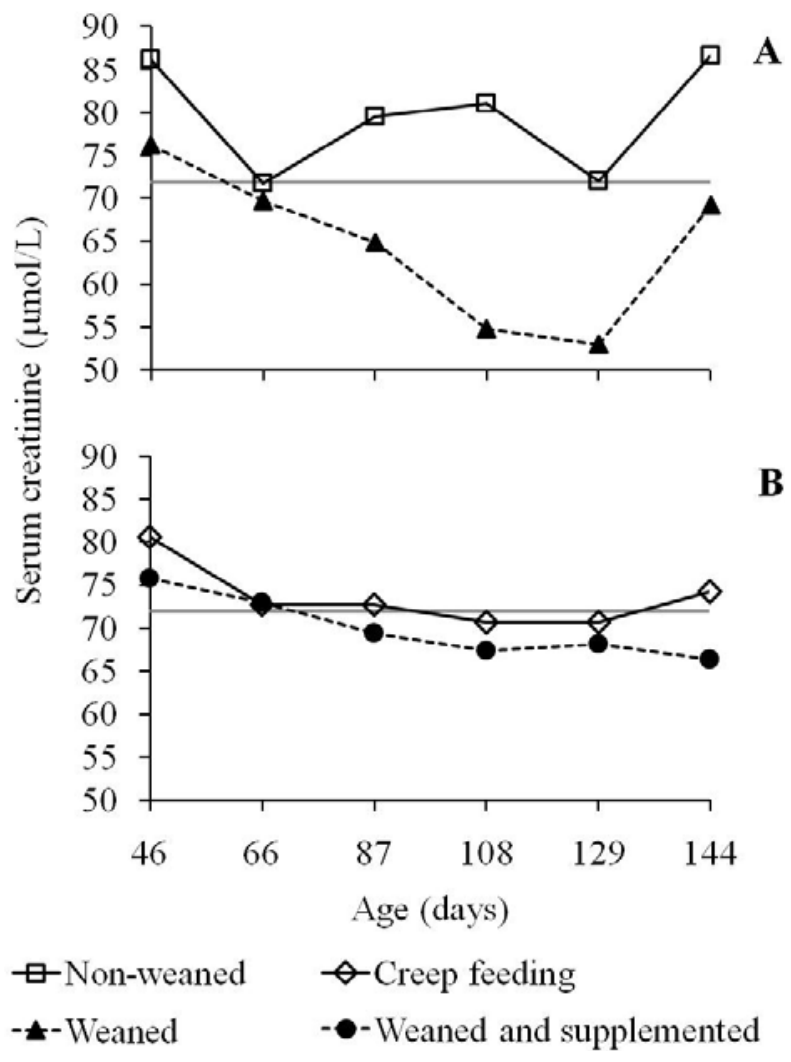

The line represents the mean serum creatinine $(71.92 \mu \mathrm{mol} / \mathrm{L})$ for all systems.

Figure 2 - Dynamic of serum creatinine levels in relation to age of lambs subjected to systems without (A) and with (B) supplementation.
Weaning changed lamb energetic status by modifying $(\mathrm{P}<0.05)$ serum cholesterol (Table 4$)$, which corresponded to $2.24 \mathrm{mmol} / \mathrm{L}$ in suckling and $1.91 \mathrm{mmol} / \mathrm{L}$ in weaned animals. These values remained close to the maximum established for adult sheep (1.97 mmol/L; Table 4).

Higher serum cholesterol in suckling lambs was related to the higher energy intake as fat provided by the milk. On the other hand, weaning caused a decrease in serum cholesterol, which remained below those observed in suckling lambs until the end of the trial (Figure 3). This response was also verified by Cavender et al. (1995), who reported higher serum cholesterol and LDL levels in lambs before weaning, indicating the intensification of lipid metabolism through suckling. Thus, it was confirmed that milk is an important source of energy and improves the energy status of grazing lambs.

Interaction between weaning and supplementation $(\mathrm{P}<0.05)$ was observed for serum glucose (Table 4 ), which was lower in weaned and non-supplemented lambs (Table 6). Serum glucose ranged from 4.27 to $5.09 \mathrm{mmol} / \mathrm{L}$, values near to the maximum established for adult sheep $(4.44 \mathrm{mmol} / \mathrm{L}$, Table 4).

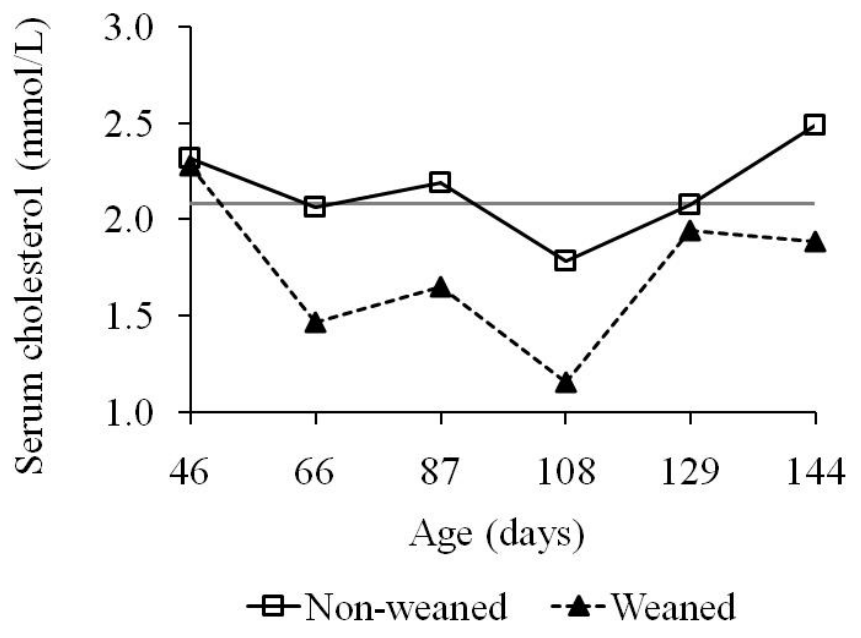

The line represents the mean serum cholesterol $(2.08 \mathrm{mmol} / \mathrm{L})$ for all systems.

Figure 3 - Dynamic of serum cholesterol levels in relation to age of lambs subjected or not to weaning.

Table 6 - Weaning and supplementation interaction for serum glucose in lambs raised on Tifton-85 pasture

\begin{tabular}{lccc}
\hline $\begin{array}{l}\text { Blood } \\
\text { metabolite }\end{array}$ & Weaning & \multicolumn{2}{c}{ Supplementation } \\
\cline { 3 - 4 } & & $\mathrm{S}_{0}$ & $\mathrm{~S}_{1}$ \\
\hline Glucose $(\mathrm{mmol} / \mathrm{L})$ & $\mathrm{W}_{0}$ & $4.67 \mathrm{Aa}$ & $4.94 \mathrm{Aa}$ \\
& $\mathrm{W}_{1}$ & $4.27 \mathrm{Bb}$ & $5.09 \mathrm{Aa}$ \\
\hline
\end{tabular}

$\mathrm{W}_{0}$ - non-weaned; $\mathrm{W}_{1}$ - weaned; $\mathrm{S}_{0}$ = non-supplemented; $\mathrm{S}_{1}$ - supplemented. Means followed by different capital letters in the same column, and different lowercase letters in the same row show difference on Tukey test $(\mathrm{P}<0.05)$. 
The intake of milk, concentrated supplement or both resulted in higher production of rumen propionate, which is the main substrate for gluconeogenesis in ruminants. The main metabolic adaptation in the pre-ruminant phase is liver modification of glycolytic to glycogenic status, a process that is intensified by increased production and absorption of rumen propionate (Baldwin et al., 2004). There is high correlation between uptake of propionate and glucose synthesis in the liver, resulting in increased availability of glucose to peripheral tissues (Kozloski, 2009). This is confirmed by blood glucose levels near or above the average $(4.73 \mathrm{mmol} / \mathrm{L})$ during the trial period in lambs which ingested milk and/or concentrated supplement (Figure 4).

Despite the higher serum aspartate aminotransferase observed in suckling lambs compared with the weaned (126.3 vs. $115.3 \mathrm{U} / \mathrm{L}, \mathrm{P}<0.05$ ), and those observed in nonsupplemented lambs compared with supplemented ones (130.3 vs. $111.3 \mathrm{U} / \mathrm{L}, \mathrm{P}<0.05)$, they remained within the reference range for adult sheep (60 - $280 \mathrm{U} / \mathrm{L}$; Table 4).

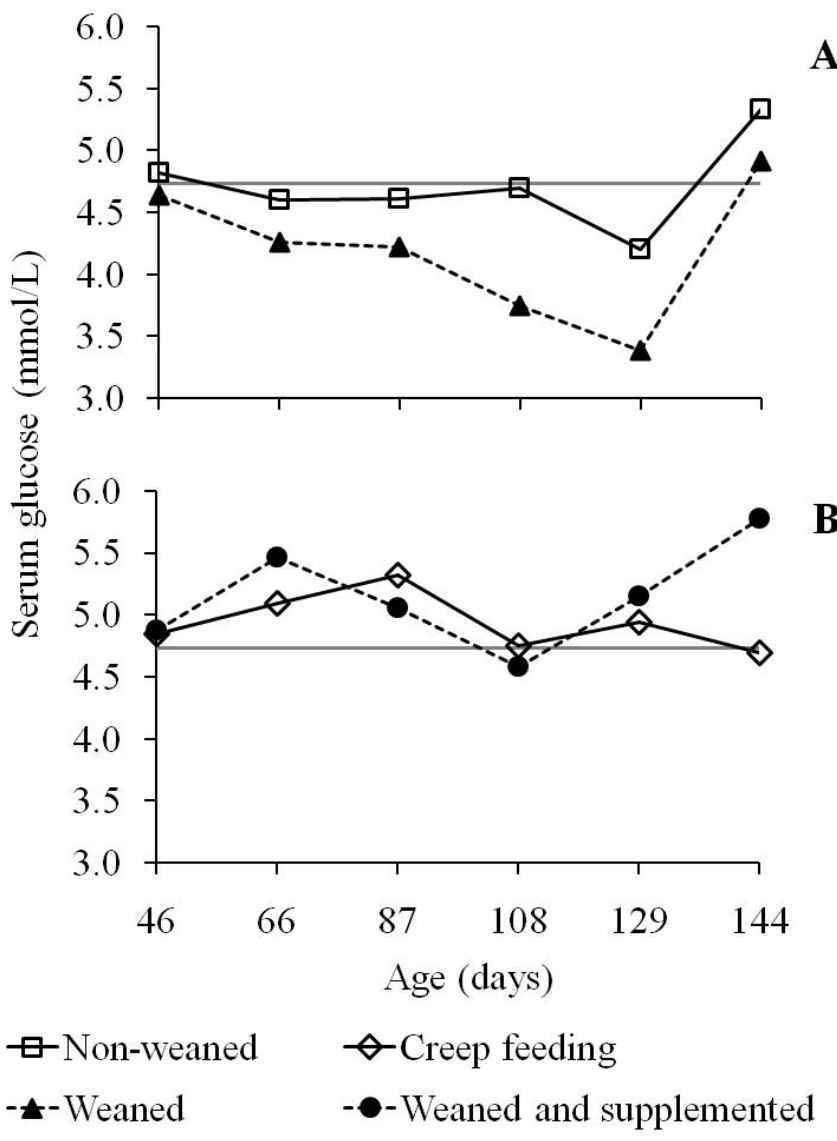

The line represents the mean serum glucose $(4.73 \mathrm{mmol} / \mathrm{L})$ for all systems.

Figure 4 - Dynamic of serum glucose levels in relation to age of lambs subjected to systems without (A) and with (B) supplementation.
Serum aspartate aminotransferase increased progressively during the trial period (Figure 5), which reflects the increase in hepatic activity with lamb increasing age.

Aspartate aminotransferase plays an important role in the metabolism of gluconeogenesis and urea synthesis (Tennant \& Center, 2008), which explains its higher activity in suckling lambs and non-supplemented lambs, respectively. Considering that the energy requirements were met through milk intake, some protein coming from forage was directed to gluconeogenesis and subsequent glycogenesis in the liver, determining higher levels of glucose and increased aspartate aminotransferase activity in suckling lambs. Shi-Gang et al. (2010) also reported that animals weaned at 40 days of age showed lower serum aspartate aminotransferase compared with suckling lambs (95.8 vs. 117.4 U/L on average, respectively).

The low energy intake promoted greater production of urea and, consequently, the increase in aspartate aminotransferase activity in non-supplemented lambs.

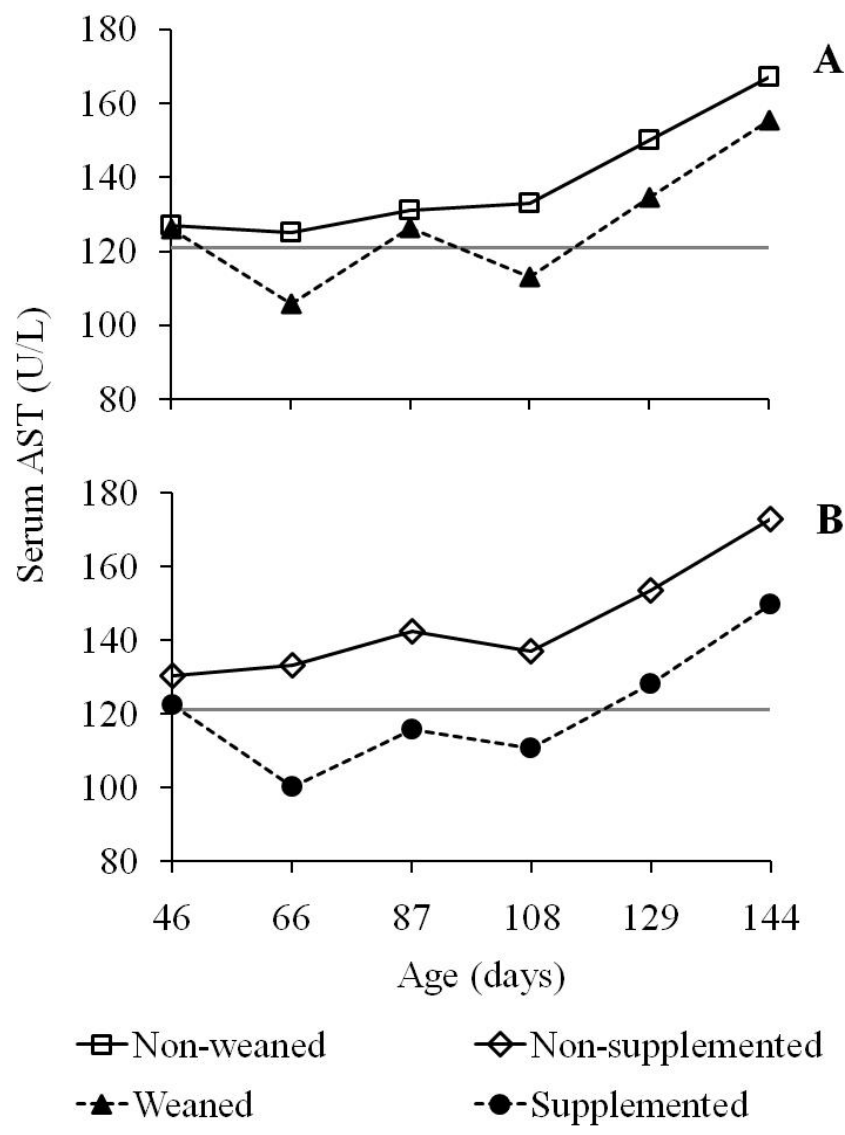

The line represents the mean serum AST (120.92 U/L) for all systems.

Figure 5 - Dynamic of serum aspartate aminotransferase (AST) levels in relation to age of lambs subjected or not to weaning (A) and supplementation (B). 
Despite not having been measured, the increase of urea excretion via urine in these animals could explain the similarities in serum urea between the production systems. Budag et al. (2009) also reported increase in the serum aspartate aminotransferase and urea in weaned lambs fed diets composed of legume with low energy content.

Growth measurements were related to the blood metabolic parameters assessed in lambs (except for serum urea). Unsuitable metabolic status to high performance was found in response to early weaning and characterized by low levels of blood metabolites (serum albumin, creatinine, cholesterol, glucose and aspartate aminotransferase). This way, low ADG, final BW and final BSC were observed for weaned and non-supplemented lambs. Suckling and concentrate supplementation increased levels of blood metabolites (except for serum cholesterol and aspartate aminotransferase in supplemented lambs) and promoted better metabolic status. Consequently, suckling lambs and supplemented lambs showed higher ADG, final BW and final BCS. Thus, changes in metabolic status may affect the performance of grazing lambs. Therefore, high quality feeding characterized by suckling and concentrate supplementation positively affects lamb metabolic status and influences higher growth rates for grazing lambs.

\section{Conclusions}

Early weaning generates unsuitable metabolic profile to obtain satisfactory results of performance and body condition on slaughter, and may not be recommended as single strategy to raise lambs on pasture. Daily supplementation with protein-energy concentrate in $20 \mathrm{~g} / \mathrm{kg}$ of lamb body weight on dry matter basis positively influences lamb performance and metabolic profile, presenting similar response to suckling. If early weaning is a necessary management practice into the production system, the post-weaning supplementation with high quality concentrate should be used to improve metabolic condition and performance of grazing lambs.

\section{References}

ALLEN, M.S. Physical constraints on voluntary intake of forages by ruminants. Journal of Animal Science, v.74, p.3063-3075, 1996.

BALDWIN, R.L.; McLEOD, K.R.; KLOTZ, J.L. et al. Rumen development, intestinal growth and hepatic metabolism in the pre- and postweaning ruminant. Journal of Dairy Science, v.87, n.3, p.55-65, 2004.

BUDAG, C.; TAS, A.; TAS, E. Effects of vetch grain as feed on certain blood parameters in lambs. Agricultural Journal, v.4, p.175-178, 2009.
BURNS, J.C.; LIPPKE, H.; FISHER, D.S. The relationship of herbage mass and characteristics to animal responses in grazing experiments. In: MARTEN, G.C. (Ed.) Grazing research: design, methodology and analysis. Madison: Crop Science Society of America, 1989. p.7-20.

CALDEIRA, R.M. Monitorização da adequação do plano alimentar e do estado nutricional em ovelhas. Revista Portuguesa de Ciências Veterinárias, v.100, p.125-139, 2005.

CALDEIRA, R.M.; BELO, A.T.; SANTOS, C.C. et al. The effect of body condition score on blood metabolites and hormonal profiles in ewes. Small Ruminant Research, v.68, p.233-241, 2007.

CAMPBELL, A.G. Grazed pasture parameters. Pasture dry matter production and availability in a stocking rate and grazing management experiment with dairy cow. Journal of Agricultural Science, v.67, n.2, p.199-210, 1966.

CARVALHO, S.; BROCHIER, M.A.; PIVATO, J. et al. Ganho de peso, características da carcaça e componentes não-carcaça de cordeiros da raça Texel terminados em diferentes sistemas alimentares. Ciência Rural, v.37, n.3, p.821-827, 2007.

CAVENDER, C.P.; TURLEY, S.D.; DIETSCHY, J.M. Sterol metabolism in fetal, newborn, and suckled lambs and their response to cholesterol after weaning. The American Journal of Physiology, v.269, p.331-340, 1995.

ECKERSALL, P.D. Proteins, proteomics, and the dysproteinemias. In: KANEKO, J.J.; HARVEY, J.W.; BRUSS, M.L. (Eds.) Clinical biochemistry of domestic animals. 6.ed. San Diego: Academic Press, 2008. p.114-155.

ELEJALDE, D.A.; ROCHA, M.G.; BREMM, C. et al. Desempenho de cordeiras em pastagens de azevém e de milheto sob suplementação. Revista Brasileira de Zootecnia, v.39, n.4, p.707-715, 2010.

FERNANDES, S.R.; MONTEIRO, A.L.G.; SILVA, C.J.A. et al. Desmame precoce e a suplementação concentrada no peso ao abate e nas características de carcaça de cordeiros terminados em pastagem. Revista Brasileira de Saúde e Produção Animal, v.12, n.2, p.527-537, 2011.

GORDON, H.M.; WHITLOCK, H.V. A new technique for counting nematode eggs in sheep faeces. Journal of the Council of Scientific and Industrial Research, v.12, p.50-52, 1939.

HODGSON, J. Grazing management: science into practice. New York: Longman Handbooks in Agriculture, 1990. 203p.

KANEKO, J.J.; HARVEY, J.W.; BRUSS, M.L. Clinical biochemistry of domestic animals. 6.ed. San Diego: Academic Press, 2008. $916 \mathrm{p}$.

KOZLOSKI, G.V. Bioquímica dos ruminantes. 2.ed. Santa Maria: Editora da UFSM, 2009. 216p.

MOLENTO, M.B.; TASCA, C.; GALLO, A. et al. Método Famacha como parâmetro clínico individual de infecção por Haemonchus contortus em pequenos ruminantes. Ciência Rural, v.34, n.4, p.1139-1145, 2004.

MOTT, G.O.; LUCAS, H.L. The design, conduct and interpretation of grazing trials on cultivated and improved pastures. In: INTERNATIONAL GRASSLAND CONGREES, 6., 1952, State College. Proceedings... State College: Pensylvania State College Press, 1952. p.1380-1385.

NATIONAL RESEARCH COUNCIL - NRC. Nutrient requeriments of dairy cattle. 7.rev.ed. Washinton: National Academy Press, 2001. 381p.

POLI, C.H.E.C.; MONTEIRO, A.L.G.; BARROS, C.S. et al. Produção de ovinos de corte em quarto sistemas de produção. Revista Brasileira de Zootecnia, v.37, n.4, p.666-673, 2008.

POPPI, D.P.; McLENNAN, S.R. Protein and energy utilization by ruminants at pasture. Journal of Animal Science, v.73, p.278-290, 1995.

PULINA, G.; NUDDA, A. Milk production. In: PULINA, G., BENCINI, R. (Eds.) Dairy sheep nutrition. Wallingford: CABI Publishing, 2004. p.1-12. 
RIBEIRO, T.M.D.; MONTEIRO, A.L.G.; PRADO, O.R. et al. Desempenho e características das carcaças de cordeiros em quatro sistemas de produção. Revista Brasileira de Saúde e Produção Animal, v.10, n.2, p.366-378, 2009.

RICHARDSON, E.C.; HERD, R.M.; ARCHER, J.A. et al. Metabolic differences in Angus steers divergently selected for residual feed intake. Australian Journal of Experimental Agriculture, v.44, p.441-452, 2004.

RUSSEL, A.J.F.; DONEY, J.M.; GUNN, R.G. Subjective assessment of body fat in live sheep. Journal Agricultural Science, v.72, p.451-454, 1969.

SHI-GANG, Y.; HAI-YING, L.; CHAO, F. et al. Effect of early weaning on biochemical indicator in serum of Xinjiang local sheep breeds in China. Journal of Animal and Veterinary Advances, v.9, p.2659-2664, 2010.

SILVA, D.J.; QUEIROZ, A.C. Análise de alimentos: métodos químicos e biológicos. 3.ed. Viçosa, MG: Universidade Federal de Viçosa, 2002. 235p.

SNIFFEN, C.J.; O'CONNOR, J.D.; VAN SOEST, P.J. et al. A net carbohydrate and protein system for evaluating cattle diets: II.
Carbohydrate and protein availability. Journal of Animal Science, v.70, p.3562-3577, 1992.

SOARES, A.B.; MEZZALIRA, J.C.; BUENO, E.A.C. et al. Efeitos de diferentes intensidades de pastejo em pastagem nativa melhorada sobre o desempenho animal. Revista Brasileira de Zootecnia, v.35, n.1, p.75-83, 2006.

SOUZA, R.A.; VOLTOLINI, T.V.; PEREIRA, L.G.R. et al. Desempenho produtivo e parâmetros de carcaça de cordeiros mantidos em pastos irrigados e suplementados com doses crescentes de concentrado. Acta Scientiarum Animal Science, v.32, n.3, p.323-329, 2010.

TENNANT, B.C.; CENTER, S.A. Hepatic function. In: KANEKO, J.J.; HARVEY, J.W.; BRUSS, M.L. (Eds.) Clinical biochemistry of domestic animals. 6.ed. San Diego: Academic Press, 2008. p.379-412.

VAN SOEST, P.J.; ROBERTSON, J.B.; LEWIS, B.A. Methods for dietary fiber, neutral detergent fiber, and no starch polysaccharides in relation to animal nutrition. Journal of Dairy Science, v.74, n.10, p.3583-3597, 1991. 